\title{
Effect of Neurodynamics on Pain and Paresthesia in Post- operated Patients with Lumbar Disc Herniation
}

\author{
Ki-ryong Jang', Ji-Won Park², Kiseok Nam³ \\ 'Department of Physical Therapy, S Pohang Hospital, Pohang; ${ }^{2}$ Department of Physical Therapy, College of Bio and Medical Science, Daegu Catholic \\ University, Gyeongsan; ${ }^{3}$ Department of Physical Therapy, Yeungnam University College, Daegu, Korea
}

Purpose: Some patients who have undergone surgery due to lumbar disc herniation still complain of leg pain and other abnormal sensations. Therefore, the study examined the effects of the neurodynamics on pain and other abnormal nerve sensations in post-operated patients with lumbar disc herniation.

Methods: The participants of this study comprised 20 adults (10 males and 10 females) who were diagnosed with lumbar disc herniation. The subjects were classified into two groups of 10 patients each in the lower extremity neurodynamics (LEN) and lumbar stabilization exercise (LSE) groups. Each intervention was applied twice a day for one week and was composed of two different exercise patterns; one was applied by a therapist, and the other was performed by the patients themselves. The data were analyzed using assessment methods of Digital Infrared Thermal Imaging (DITI), Toronto clinical neuropathy scoring system (TCNSS), Sympathetic Skin Response (SSR) test, and Oswestry Disability Index (ODI) scale.

Results: Significant differences in TCNSS, DITI, ODI scale were observed between the LEN and LSE group $(p<0.01)$. On the other hand, there was no significant difference in the SSR test between pre and post-treatment $(p>0.05)$.

Conclusion: The results indicated that neurodynamics treatment is effective in pain reduction and abnormal sensations, such as leg muscle cramps, in post-operated patients with lumbar disc herniation.

Keywords: Neurodynamics, Lumbar disc herniation, Paresthesia.

\section{서 론}

요통은 모든 근골격계 증상 중 가장 흔하며 일차 진료의를 방문하는 주 원인 중 하나다. 요통은 일생 동안 대개 한 번은 겪고, 유병률은 약 4-33\%에 이른다. 요통 진단과 치료에 대하여 광범위한 연구들이 있었 지만 이는 아직 난제로 남아있으며, ${ }^{2} 1990$ 년대에 효과적인 치료 대부 분이 규명되지 않았다. 요통을 일으키는 원인 중 하나인 신경근의 압 박은 하지 통증의 중요한 원인이고 척추사이원반 섬유테의 외측벽이 요통의 의미 있는 원인이라고 하였다. 통증은 통증 연구 국제 연맹에 의하면 “실제적 또는 잠재적 조직 손상 또는 이러한 손상에 관해 기술 되는 불쾌한 감각/감정적 경험이라고 정의되었다. 5 요통의 원인 중 허 리원반 탈출증은 L4-L5와 L5-S1에서 80\% 이상 발생하며 보존적 치료 를 시행해도 효과가 없는 경우 수술적 요법을 적용한다. 미세 척추사 이원반 절제술에서 $90 \%$ 이상의 환자들이 증상이 완화되어 이전의
활동을 다시 할 수 있었다. ${ }^{6}$ 그러나 작은 절개부위로는 뼈와 인대의 병변에 접근하기가 쉽지 않다는 점에서 미세 척추사이원반 절개술 을 비판하였고, 척추사이원반 절제술 동안 시야가 좁아 노출된 신경 근을 더욱 견인해야 하므로 신경근의 손상을 초래한다고 하였다.7.8

신경계는 손상받지 않은 상태에서 정상적으로 움직이기 위해서는 기계적 기능, 즉 긴장(tension)을 견디고, 조직 내에서의 활주(sliding) 하고, 압박(compression)되는 것을 성공적으로 수행할 수 있어야 한 다. 신경의 활주 현상에 의해 신장이 시작된 부위로 신경 조직을 이동 시킴으로써 긴장의 기울기를 감소시킬 수 있으며 신경계의 긴장을 균등하게 분산시켜 특정 부위의 긴장이 높아지지 않도록 한다. 신경 의 길이가 8-15\% 신장되면 말초신경의 혈류는 차단되지만, ${ }^{9}$ 정중신경 을 포함하고 있는 조직은 팔꿉관절이 완전 굽힘상태에서 완전 폄위 치로 바뀔 때에 약 $20 \%$ 나 늘어난다. ${ }^{10}$ 이때 몸쪽부분과 먼쪽부분에 서 긴장이 가해지는 부위를 향해 신경의 활주가 일어나지 않는다면, 
신경은 허혈(ischemia)에 빠진다. 또한 신경계에 비정상적인 비틀림 (twist)이 발생한 경우, 말초신경의 혈류는 실제로 신경벽 혈관에 분포 하는 신경에 의해 조절된다.111, 통각수용기와 교감신경섬유가 이와 같은 종류의 신경섬유이며, 통제를 담당한다. 자극을 받게 되면 통증 을 유발할 수 있을 뿐만 아니라, ${ }^{13}$ 신경의 결합조직에 있는 통각수용 기(C섬유)에 의해 국소혈관이 확장된다. 신경의 통각수용기를 자극 하면 자극하는 부분의 신경내 혈류 증가가 유발된다. ${ }^{14}$ 반복적인 기계 자극은 신경내 혈류를 증가시키는 경향이 있고, 과도한 자극의 경우 에는 신경에 염증이나 부종을 발생시킨다.

신경조직의 압박과 긴장은 신경조직의 허혈과 축삭수송(axonal transport)의 저하를 초래한다. ${ }^{5}$ 이러한 신경의 압박이나 긴장을 완화 함으로써 신경의 생리학 및 관련 증상들을 개선할 수 있다. 신경가동 술(neurodynamics)은 통증에 관한 물리치료적 접근 방법 중 하나이며 신경조직의 생리학적 및 생체역학적인 부분 뿐 아니라 신경조직의 주 변인 결합조직에도 통증에 관련된 영향을 미친다. ${ }^{16}$ 또한, 기계적 기능 의 치료를 통해 생리학적 호전을 도모하는 것은 신경동역학적 개념의 불가결한 부분이며, 치료에 있어서 대단히 효과적이라 하였다.16-18

신경가동술은 기계적 수용 감각의 즉각적인 감소를 유발하여 가 쪽위관절융기 통증 19 및 목뼈 통증을 감소시킨다. ${ }^{20,21} \mathrm{Elvey}$ 는 ${ }^{21}$ 신경이 주변 조직으로부터 활주가 일어나는 신경가동술을 적용했을 때 목 통증을 감소시키는 다른 치료보다 효과적이고, 어깨나 등뼈통증에 도수치료보다 더 효과적이라고 하였고 손목터널 증후군 환자에서 보 존적 치료에 신경 활주 방법을 추가하면, 수술의 필요성을 $29.8 \%$ 까지 감소시킬 수 있다고 한다. 그러나 현재까지 신경가동술에 대한 연구 는 팔과 목빼, 또는 허리원반 탈출증으로 인한 증상들에 대한 기능적 및 신경생리학적 효과에 치중되어 있고 허리원반 탈출증 수술로 인한 환자의 이상감각과 교감신경에 대한 연구는 드물다. 또한, 신경가동술 은 척추사이원반 압박으로 인한 신경뿌리병증에 관하여 검사와 치료 에 많이 이용되어 왔을 뿐, 수술 이후의 중재에 관한 연구는 부족한
실정이다. 이에 본 연구에서는 신경가동술이 허리원반 탈출증 수술 후 환자의 이상감각과 교감신경에 미치는지 영향을 알아보고자 한다.

\section{연구 방법}

\section{1. 연구대상 및 기간}

본 연구는 포항 소재 $S$ 병원에 입원하여 물리치료를 받고 있는 환자 중 연구에 참여하기로 동의하였고 방사선 검사에서 허리원반 탈출 증 진단을 받은 성인 남녀 10 명을 대상으로 하였다. 연구에 참여한 대 상자의 선정 기준은 다음과 같다. 첫째, 척추사이원반탈출로 인해 $\mathrm{L} 4$, $\mathrm{L} 5, \mathrm{~S} 1$ 신경근 중 단일 압박으로 진단받은 자, 둘째, 수술 후 허리 및 다 리의 통증과 이상 감각이 남아 있는 자, 셋째, 허리 수술 이외 다른 수 술을 받은 경험이 없는 자, 넷째, 척추사이원반탈출의 재발로 인해 수 술을 받지 않은 자, 다섯째, 당뇨, 만성 신부전 등 자율신경계에 영향 을 미치는 병력이 없는 자, 여섯째, 수술 후 기간이 일주일이 경과한 자(Table 1).

Table 1. General characteristics of subjects

$(N=20)$

\begin{tabular}{lcc}
\hline Variables & LEN $(\mathrm{n}=10)$ & LSE $(\mathrm{n}=10)$ \\
\hline Gender $(\mathrm{n})$ & 4 & 6 \\
Male & 6 & 4 \\
Female & $46.40 \pm 3.43$ & $48.40 \pm 3.03$ \\
Age $(\mathrm{yr})$ & $166.40 \pm 3.96$ & $166.40 \pm 3.96$ \\
Body Height $(\mathrm{cm})$ & $63.60 \pm 3.41$ & $68.50 \pm 3.87$ \\
Body weight $(\mathrm{kg})$ & & \\
Operation site & 1 & 2 \\
L4 & 7 & 6 \\
L5 & 2 & 2 \\
S1 & & \\
\hline
\end{tabular}

Values are mean $\pm S D$.

LEN: Lower Extremity Neurodynamic, LSE: Lumbar Stabilization Exercise.
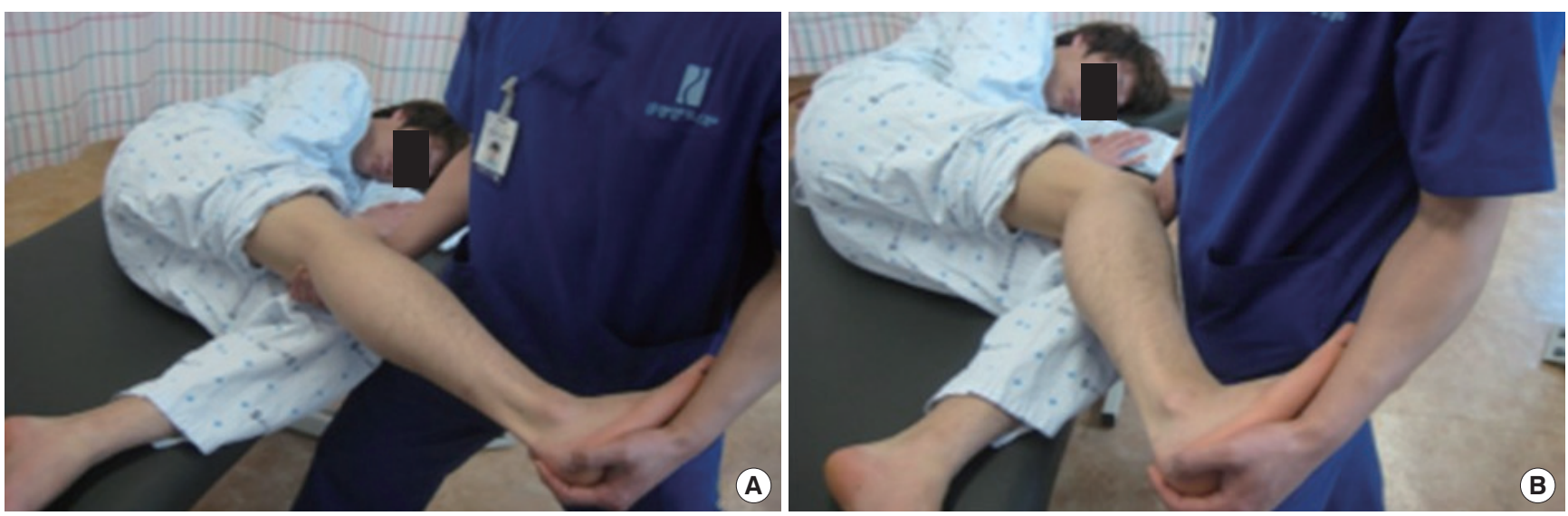

Figure 1. Slider technique. 


\section{2. 실험 방법}

연구 대상자들은 총 20명으로 신경가동술적용군(Lower Extremity Neurodynamics, LEN) 10명, 요부 안정화 운동군(Lumbar Stability Exercise, LSE) 10 명으로 나누었고, 대상자들은 모두 무작위로 배치하였 다. 신경가동술적용군, 요부 안정화 운동군은 모두 열, 전기치료로 이 루어지는 기존의 물리치료와함께 적용하였다.

신경가동술은 1 주 동안 1 일 2회 적용하였다. 환자는 slump 자세를 옆으로 하여 누운 후 목뼈는 굽힘하고 엉덩관절은 $60^{\circ}$ 정도 굽힌 후 환 자의 환측 다리로 하여금 신경에 저항이 나타나기 직전까지 무릎관 절을 폄시키며 이후 무릎관절을 굽힘과 함께 발목 관절을 등쪽굽힘 시키는 동작을 치료사가 적용하였다. 이후 다시 무릎관절을 폄시키고 발목관절을 원위치로 움직이는 동작을 반복하였다. 그리고 치료사가 적용한 동작을 환자 스스로 자가치료가 가능하도록 슬링을 이용하 여 대상자에게 교육하여 $3 \mathrm{set}$ 를 시행하도록 하였다. 이후 5 분의 휴식 후 환자에게 슬링을 이용하여 목뼈는 굽힐 때 무릎관절도 굽히는 동
작의 자가치료를 교육 후 시행하도록 하였다. 이 방법은 척추사이구멍 을 통해 빠져나오는 신경뿌리가 척추사이구멍 내에서의 가동성을 원 활히 할 수 있도록 한다. 이러한 치료방법을 slider technique이라고 하 는데 이 방법을 반복하여 15-20회를 목벼를 펼 때 무릎관절도 펴는 신 경역동학 자가운동법을 설명 후 10 분 적용하였다(Figures 1,2 ).

요부 안정화 운동은 1주 동안 1일 2회 운동으로 2가지 운동 프로토 콜을 통해 진행하였는데 첫 번째는 환자에게 배가로근 수축 방법을 알려주고 훈련 후 흔들리는 두 줄에 양 다리를 걸어 통증이 일어나지 않는 범위안에서 그리고 배가로근은 수축하되 허리네모근의 수축은 일어나지 않도록 주의하면서 좌우로 흔들며 배가로근 수축운동을 15 분간 적용하고 5 분 휴식을 가졌고 이후 두 번째 두 줄에 양 다리를 걸고 골반에는 넓은 스트랩과 탄성밴드를 통해 허리뼈 폄근의 부담 을 덜어주어 허리를 들어 올리는 허리뼈 신전운동을 10 분 적용하였 다(Figures 3, 4).
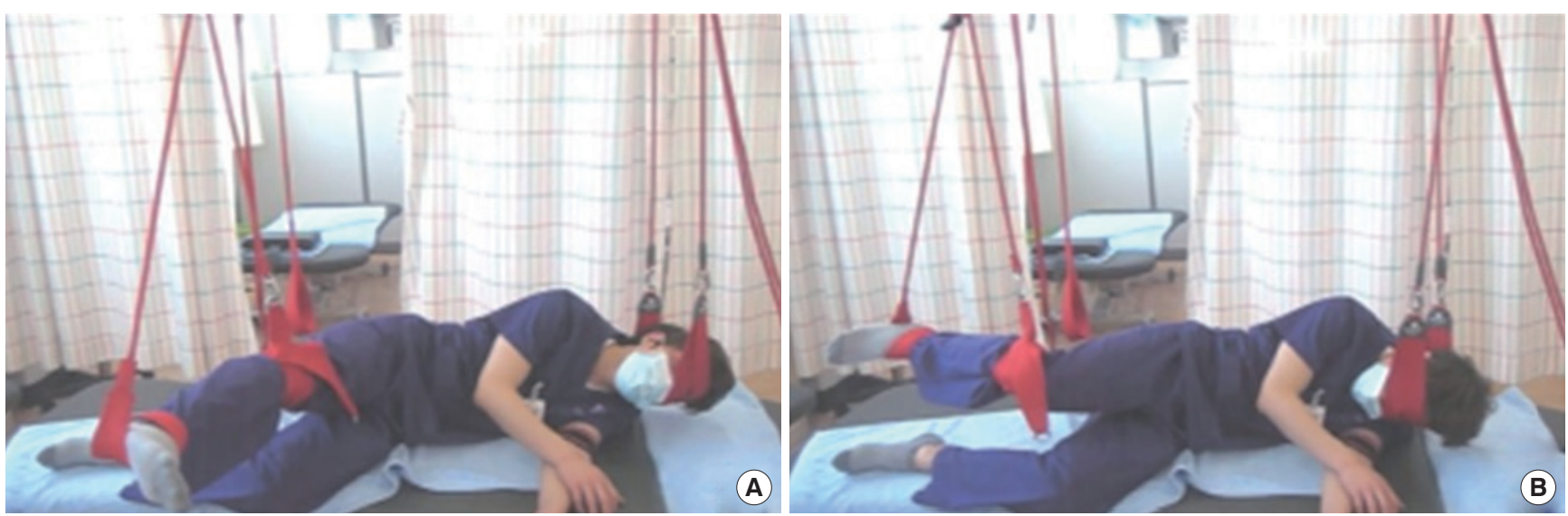

Figure 2. Self slider technique.
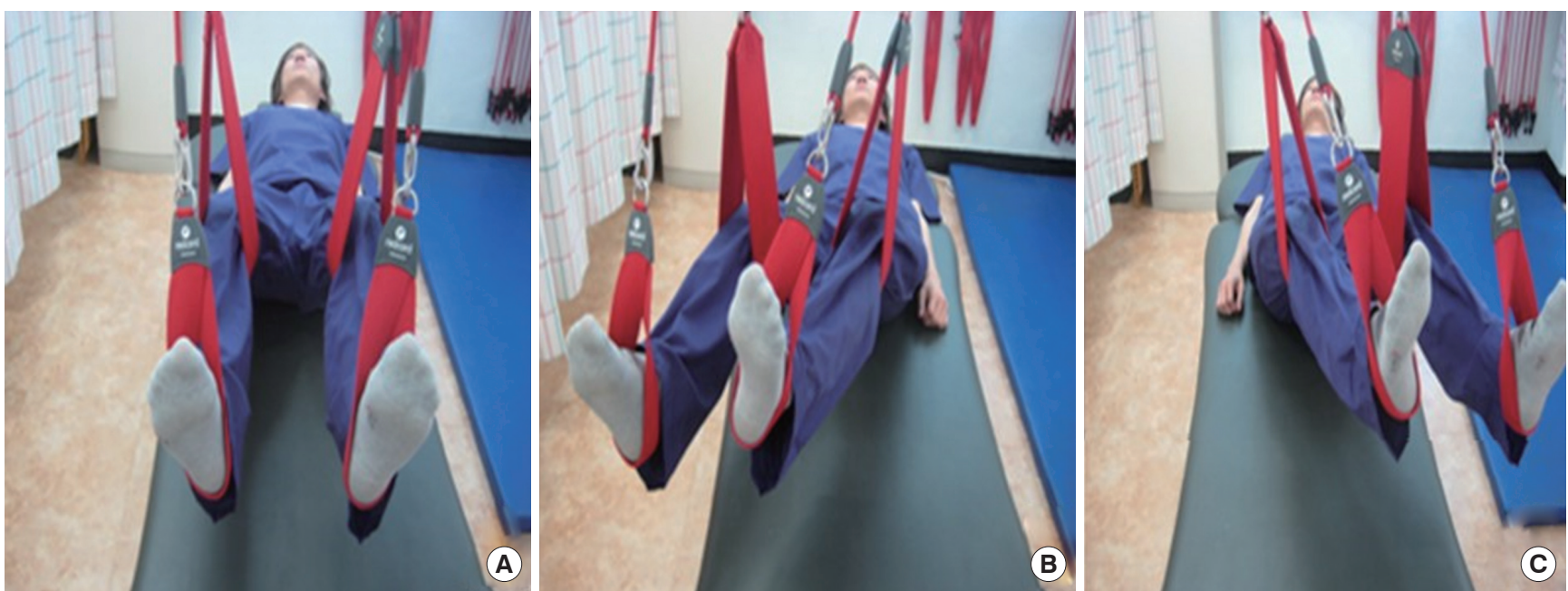

Figure 3. Lumbar stabilization exercise-1. 

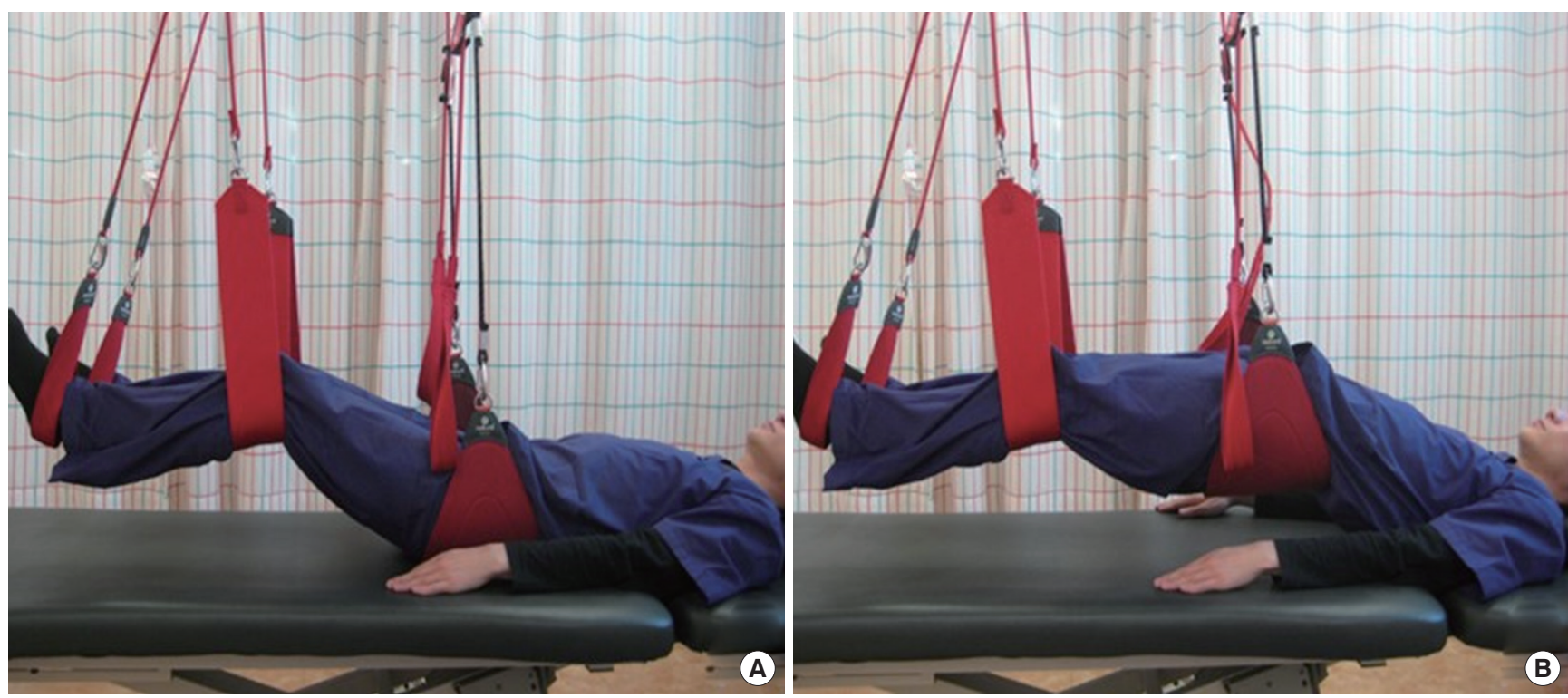

Figure 4. Lumbar stabilization exercise-2.

\section{3. 측정 도구 및 방법}

1) Toronto clinical neuropathy scoring system (TCNSS)

Brill 등 22 은 TCNSS를 말초신경병의 임상 척도로 제시하였으며, 통증 이나 감각이상 등의 주관적인 증상에 대한 6가지 항목, 위치나 통각, 냉온, 진동 감각 등의 객관적인 평가 5 가지 항목, 무릎힘줄 반사와 발 목관절 반사 2 가지 항목을 평가하여 정상인 0 점에서부터 가장 심한 경우를 19 점으로 하였다. ${ }^{23}$ 본 연구에서는 신경가동술 전과 후에 TCNSS를 측정하였다.

\section{2) 교감신경 피부반응 검사(Sympathetic Skin Response, SSR)}

교감신경 피부반응 검사(SSR)는 피부나 말초신경에 대한 전기자극 또 는 심호흡 후에 나타나는 피부반응을 이용하는 것으로써, 특히 당뇨 병성 신경병증에 대해서는 활발한 연구가 이루어져 많은 연구에서 그 유용성이 증명되었다. 본 연구에서는 근전도 기기를 사용하여 활성기 록 전극을 오른쪽 손바닥과 오른쪽 발바닥에 부착하고 접지전극을 오른쪽 손등과 오른쪽 발등에 부착 후 왼쪽 정중신경을 손목관절에 서 5 회 전기 자극하였으며, 습성화방지를 위하여 자극시점을 비규칙 적으로 적용하였고 반대쪽도 같은 방법으로 적용하였다. 신경가동술 을 적용하기 전과 후에 대상자별로 임상병리사가 측정하였다.

3) 컴퓨터 적외선 체열촬영 검사(Digital Infrared Thermal Imaging, DITI) 적외선 체열촬영은 모든 생체에서 열을 전자기 복사, 대류, 전도의 형 태로 발산한다는 이론에 근거하며 신체의 체열발산을 미세신경-혈관 조절하에서의 세포대사를 뜻하는 전도나 방사되는 에너지에 의해 형 성되는 체열지도의 형태로 보여줌으로 이러한 양상들을 관찰하여
체열촬영을 통해 신경병성, 근막성, 혈행성, 골격성과 심인성 질환들 을 알아낼 수 있게 되었고, 이 체열 촬영 검사를 통해 다른 이학적 검 사나 일반 방사선 검사, CT scan또는 근전도 검사에서 이상이 발견되 기 전에도 반복하여 나타날 수 있으며 비침습적으로 정확하게 체열 이상의 진단을 가능하게 하는 검사이다.

본 연구에서는 적외선 체열장비(IRIS XP)를 사용하였고 실내 온도 $18-21^{\circ} \mathrm{C}$ 에서 10 분간 적응 후 방비와의 거리를 $1.5 \mathrm{~m}$ 사이에 두고 체열 을 측정하였다. 환자는 검사 실시 전 3시간 이상 금식을 실시하였고 하지의 앞. 뒤면, 그리고 내측. 외측면에서 영상을 얻어 요추간판탈출 로 인해 압박이 있었던 신경근이 지배하는 피부영역의 양측의 온도 차이가 최소 $0.3^{\circ} \mathrm{C}$ 이상으로 가장 많이 차이나는 부분을 판정하였고 요부 안정화 운동 및 신경가동술 적용 전후 각각 방사선사가 측정하 였다.

4) 오스웨스트리 요통 장애 지수(Oswestry Disability Index, ODI) 요부 추간판절제술 후 기능적 결과를 측정하는데 광범위하게 사용 되어 왔으며 $\mathrm{ODI}$ 는 요통과 관련된 장애를 측정하는데 타당도와 신 뢰도가 밝혀져 있다. 본 연구에서는 요부 안정화 운동 및 신경가동술 전후각각 측정하였다. ${ }^{24,25}$

\section{4. 자료 분석}

연구결과에 대한 분석은 SPSS Version 18.0을 이용하여 통계처리 하였 고, 집단 내 전후 차이를 비교하기 위하여 윌콕슨 부호순위 검정(Wilcoxon Signed Rank Test)을 실시하였으며 유의수준 $\alpha$ 는 0.05 로 설정하 였다. 
결 과

\section{1. 연구 대상자의 일반적 특성}

본 연구에 참여한 대상자는 허리원반 탈출증 진단으로 수술 후 통증 과 다리저림 증상을 호소하는 환자 20 명이 참여하였으며, 총 20 명 중 신경가동술 적용군 10 명, 요부안정화운동 적용군 10 명으로 하였다

신경가동술적용군은 4 명, 여자 6 명이었으며, 나이는 $46.40 \pm 3.43$ 세, 키 $165.20 \pm 3.36 \mathrm{~cm}$, 체중 $63.60 \pm 3.41 \mathrm{~kg}$ 이었다. 허리원반 탈출로 인한 수술 부위는 L4 1명, L5 7명, S1 2명이었다. 요부안정화운동군은 남자 6 명, 여자 4명이었으며, 나이는 $46.40 \pm 3.03$ 세, 키 $166.40 \pm 3.96 \mathrm{~cm}$, 체중 $68.50 \pm 3.87 \mathrm{~kg}$ 이었다. 허리원반 탈출로 인한 수술 부위는 L4 2명, L5 6 명, S1 명이었다. 대상자들의 나이, 키 그리고 몸무게에서 군 간의 동 질성 검정 및 정규성 검정에서 유의한 차이가 없었다( $\mathrm{p}>0.05)$ (Table $\mathrm{l})$.

\section{2. 처치 전후에 따른 이상감각의 변화 비교}

컴퓨터 적외선 체열장비를 이용하여 측정된 DITI 검사에서 LEN 그 룹과 LSE 그룹의 측정 결과 LEN 그룹에서 처치 전 0.58 이었으며, 처치 후 0.12 로 통계학적으로 유의한 차이가 있었다 $(\mathrm{p}<0.01)$. LSE 그룹에서 는 처치 전 0.50 , 처치 후 0.65 로 통계적으로 유의한 차이가 있었다. LEN그룹과 LSE 그룹 간 처치 전 후의 반복측정 분산분석 결과, 1 주 처치 후 두 그룹 간 DITI에서 통계학적으로 유의한 차이가 있었다 $(\mathrm{p}<0.01)$ (Table 2). TCNSS 척도 점수 검사 결과 LEN 그룹에서 처치 전 5.90 이었으며, 처치 후 1.20 으로 통계학적으로 유의한 차이가 있었다

Table 2. The comparison of DITI result using Repeated measures ANOVA

\begin{tabular}{lccccc}
\hline Source & $\begin{array}{c}\text { Type III Sum } \\
\text { of Squares }\end{array}$ & df & $\begin{array}{c}\text { Mean } \\
\text { Square }\end{array}$ & $F$ & $p$ \\
\hline Intercept & 0.705 & 1 & 0.705 & 6.589 & $0.02^{*}$ \\
Operation site & 0.001 & 1 & 0.001 & 0.010 & 0.92 \\
Group & 0.503 & 1 & 0.503 & 4.892 & $0.04^{*}$ \\
Error & 1.748 & 17 & 0.103 & & \\
\hline
\end{tabular}

${ }^{*} p<0.05$.

DITI: Digital Infrared Thermal Imaging. (p<0.01). LSE그룹에서는 처치 전 6.00, 처치 후 5.20으로 통계학적으 로 유의한 차이가 있었다. LEN그룹과 LSE 그룹 간 처치 전 후의 반복 측정 분산분석 결과, 1 주 처치 후 두 그룹 간 TCNSS척도 점수에서 통 계학적으로 유의한 차이가 있었다( $\mathrm{p}<0.01)($ Table 3$)$.

\section{3. 처치 전·후에 따른 교감신경의 변화 비교}

SSR 측정 결과 잠시는 LEN 그룹에서 처치 전 왼손과 오른손바닥에 서 각각 $1,319.54 \mathrm{~ms}, 1,338.29 \mathrm{~ms}$ 이었으며, 처치 후 1,216.03 ms, 1,305.16 $\mathrm{ms}$ 이었고 발바닥의 경우 처치 전 $1,483.67 \mathrm{~ms}, 1,919.54 \mathrm{~ms}$ 이었으며, 처 치 후 $1,793.87 \mathrm{~ms}, 1,861.66 \mathrm{~ms}$ 로 손바닥의 경우는 처치 전에 비해 빨 라졌으나 통계학적으로 유의한 차이가 없었다 $(\mathrm{p}>0.05)$. 진폭은 처치 전 손바닥에서 $376.69 \mu \mathrm{V}, 416.94 \mu \mathrm{V}$ 이었으며, 처치 후 $385.61 \mu \mathrm{V}, 434.92$ $\mu \mathrm{V}$ 이었고 발바닥의 경우 $173.74 \mu \mathrm{V}, 160.38 \mu \mathrm{V}$ 이었으며 처치 후 213.08 $\mu \mathrm{V}, 202.62 \mu \mathrm{V}$ 로서 처치 전과 처치 후에 유의한 차이가 없었다(p> 0.05). LSE 그룹에서는 SSR 측정 결과 잠시는 처치 전 손바닥에서 각각 $1,291.41 \mathrm{~ms}, 1,413.26 \mathrm{~ms}$ 이었으며, 처치 후 1,337.04 ms, 1,434.68 ms이었 고 발바닥의 경우 $1,853.13 \mathrm{~ms}, 1,922.68 \mathrm{~ms}$ 이었으며, 처치 후 $1,778.39$ $\mathrm{ms}, 1,718,05 \mathrm{~ms}$ 로 손바닥의 경우는 처치 전에 비해 느려졌고 발바닥 의 경우 처치 전에 비해 빨라졌으나 통계적으로 유의한 차이는 없었 다. 진폭은 처치 전 손바닥에서 $422.62 \mu \mathrm{V}, 370.17 \mu \mathrm{V}$ 이었으며, 처치 후 $422.94 \mu \mathrm{V}, 387.30 \mu \mathrm{V}$ 이었다. 발바닥의 경우 $163.81 \mu \mathrm{V}, 180.56 \mu \mathrm{V}$ 이었으 며 처치 후 $188.83 \mu \mathrm{V}, 167.58 \mu \mathrm{V}$ 로 처치 전과 처치 후에 유의한 차이가 없었다( $\mathrm{p}>0.05)$. LEN그룹과 LSE그룹 간 처치 전과 후의 반복측정 분

Table 3. The comparison of TCNSS using Repeated measures ANOVA

\begin{tabular}{lcrrrr}
\hline Source & $\begin{array}{c}\text { Type III Sum } \\
\text { of Squares }\end{array}$ & df & $\begin{array}{r}\text { Mean } \\
\text { Square }\end{array}$ & $F$ & $P$ \\
\hline Intercept & 86.47 & 1 & 86.47 & 59.27 & $0.01^{*}$ \\
Operation site & 1.44 & 1 & 1.45 & 0.99 & 0.33 \\
Group & 42.48 & 1 & 42.48 & 29.12 & $0.01^{*}$ \\
Error & 24.8 & 17 & 0.46 & & \\
\hline
\end{tabular}

${ }^{*} \mathrm{p}<0.05$

TCNSS: Toronto clinical neuropathy scoring system.

Table 4. The comparison of SSR result using Repeated measures ANOVA

\begin{tabular}{lllcrrrr}
\hline \multirow{2}{*}{ Latency Amplitude } & $\begin{array}{l}\text { Right/Left } \\
\text { Palm\&sole }\end{array}$ & Source & $\begin{array}{c}\text { Type III Sum of } \\
\text { Squares }\end{array}$ & df & Mean Square & $F$ & p \\
\hline Latency & Left palm & Group & $12,098.75$ & 1 & $12,098.75$ & 0.079 & 0.78 \\
& Right palm & Group & $65,041.46$ & 1 & $65,041.46$ & 0.331 & 0.57 \\
& Left sole & Group & $274,681.67$ & 1 & $274,681.67$ & 1.022 & 0.33 \\
& Right sole & Group & $46,752.93$ & 1 & $46,752.93$ & 0.240 & 0.63 \\
Amplitude & Left palm & Group & $27,087.23$ & 1 & $27,087.23$ & 0.168 & 0.69 \\
& Right palm & Group & $16,027.2$ & 1 & $16,027.2$ & 0.215 & 0.65 \\
& Left sole & Group & $3,330.44$ & 1 & $3,330.44$ & 0.095 & 0.76 \\
& Right sole & Group & 991.43 & 1 & 991.43 & 0.035 & 0.85 \\
\hline
\end{tabular}

SSR: Sympathetic Skin Response. 
Table 5. The comparison of ODI result using Repeated measures ANOVA

\begin{tabular}{lccrrr}
\hline Source & $\begin{array}{c}\text { Type III Sum } \\
\text { of Squares }\end{array}$ & df & $\begin{array}{c}\text { Mean } \\
\text { Square }\end{array}$ & $\mathrm{F}$ & $\mathrm{P}$ \\
\hline Intercept & 86.47 & 1 & 86.47 & 59.27 & $0.01^{*}$ \\
Operation site & 1.44 & 1 & 1.45 & 0.99 & 0.33 \\
Group & 42.48 & 1 & 42.48 & 29.12 & $0.01^{*}$ \\
Error & 24.8 & 17 & 1.46 & & \\
\hline
\end{tabular}

${ }^{*} \mathrm{p}<0.05$.

ODI: Oswestry Disability Index.

산분석 결과, 1 주 처치 후 두 그룹 간 SSR 측정 결과값은 통계적으로 유의한 차이가 없었다 $(\mathrm{p}>0.05)($ Table 4$)$.

\section{4. 처치 전후에 따른 통증의 변화 비교}

$\mathrm{ODI}$ 척도를 이용하여 측정된 통증 점수에서 $\mathrm{LEN}$ 그룹은 처치 전 28.00 점이었으며, 처치 후 11.20 점으로 통계학적으로 유의한 차이가 있었다 $(\mathrm{p}<0.01)$. LSE그룹에서는 처치 전 26.40점이었으며, 처치 후 23.40점으로 통계학적으로 유의한 차이가 있었다 $(\mathrm{p}<0.01)$. LEN그룹 과 LSE그룹 간 처치 전과 후의 반복측정 분산분석 결과 1 주 처치 후 두 그룹 간 $\mathrm{ODI}$ 척도 점수는 통계학적으로 유의한 차이가 있었다 $(\mathrm{p}<0.05)($ Table 5).

\section{고 찰}

신경가동술(neurodynamics)은 움직임과 관련된 신경생리학적 변화 를 설명해주며 또 신체, 정신 활동 중에 중추신경계에서 어떠한 일들 이 벌어지는지 추정할 수 있게 해준다. ${ }^{26}$ 또한 신경내 혈류 변화(intraneural blood flow), ${ }^{27}$ 신경 염증(neural inflammation), ${ }^{14}$ 기계적 민감성 (mechanosensitivity), ${ }^{28}$ 그리고 근육반응 ${ }^{29}$ 의 메커니즘을 포함한다. 그 러나 허리 수술 후 신경조직 가동성에 대한 무작위 배정 연구에서, Scrimshaw와 Maher ${ }^{30}$ 는 수술 후 프로그램에 신경조직 가동성 개념 을 더하여 치료해도 추가적인 이득이 없다고 보고하였으나 이 결과 는 환자의 이질성(척추후궁절제술, 척추사이원반 제거술 등)이 연구 의 결과에 영향을 끼친 것으로 보인다는 주장도 있다. 따라서 본 연구 에서는 환자의 이질성을 최소화하기 위해 단일 level의 척추사이원반 제거술을 적용한 환자를 선정대상으로 기존물리치료와 신경가동술 을 적용하였다.

환자의 이상감각을 알아보기 위해 TCNSS 척도와 DITI 척도를 이 용하였다. TCNSS 척도 점수에서 요부안정화운동군은 처치 전 6.00 점, 처치 후 5.2 점으로 평균 0.8 점 감소하였고 신경가동술 적용군은 처치 전 5.9점, 처치 후 1.2 점으로 평균 4.7점 감소한 것으로 나타났다. DITI값에서 요부안정화 운동군은 처치 전 0.50 , 처치 후 0.65 로 평균 0.15 증가한 것으로 나타났고, 신경가동술 적용군에서는 처치 전 평
균 0.58 , 처치 후 평균 0.12 로 평균 0.46 감소한 것으로 나타났다. TCNSS, DITI 모두에서 신경가동술 적용군이 더 많이 감소하며 통계 학적으로 유의한 차이가 나타났다. Bove 등른 신경근(nerve roots)주 위의 결합조직을 강하게 신장하면 연결된 등쪽신경근의 감각섬유가 활성화된다고 하였고, 체표면 온도의 변화는 반사적 교감성 혈관수 축(reflex sympathetic vasoconstriction)과 연관된 회귀수막신경의 활성 화로 이루어진다고 하였다. ${ }^{31}$ Mark 등 ${ }^{32}$ 의 연구에서는 6주, 24주의 TCNSS 척도 점수를 비교한 결과 실험군과 대조군 사이에서 이상감 각과 통증에 유의한 차이가 없다고 보고하였으며, Ghavami 등 ${ }^{33}$ 의 연 구에서는 74명을 대상으로 통증, 이상감각을 TCNSS척도 점수를 비 교하여 확인한 결과 중재 후 평균 점수가 감소하는 유의한 차이가 있 다고 보고하였다. 이는 신경가동술이 교감신경계 및 그와 연관된 신 경, 주변조직의 기계적 및 생리학적 기능을 증진시켜 TCNSS에 유의 한 영향을 미친 것으로 생각된다.

환자의 교감신경 변화를 알아보기 위해 근전도 장비를 통한 교감 신경피부반응검사(SSR) 중 잠복시와 진폭에서 유의한 차이가 나타나 지 않았는데 이는 신경근에 적절한 생리학적 영향을 주어도 교감신 경계통에 관련한 혈류의 변화에는 영향을 주지만 신경 전도 속도와 자율신경계에 대한 피부반응의 효과는 미미한 것으로 보이며, $\mathrm{Kim}$ 등 34 은 정상 성인을 대상으로 저주파, 고주파, 간섭자 전기자극을 적 용하여 교감신경 피부반응 검사를 실시한 결과 통해 통계학적으로 유의한차이를 보이지 않았다고 보고하여 본 연구 결과와 일치했다.

환자의 통증을 알아보기 위하여 사용된 $\mathrm{ODI}$ 는 요통환자의 증상 완화와 약화를 운동 기능적으로 측정할 수 있도록 고안된 도구이다. 본 연구에서는 $\mathrm{ODI}$ 점수에서 요부 안정화 운동군은 처치 전 26.40점, 처치 후 23.40점으로 평균 3.00점 감소한 것으로 나타났고, 신경가동 술 적용군은 처치 전 28.00점, 처치 후 11.20 점으로 평균 16.80 점 감소 한 것으로 나타났다. 신경가동술 적용군에서 특히 평균값이 감소한 것은 신경가동술은 하나 혹은 여러 관절의 움직임에 의하여 신경내 부의 긴장이 증가하면서 신경말단의 연장이 일어나고 근육내 근방 추와 골지건기관의 역할을 최대한으로 이끌어 내어 뒤넙다리근의 유 연성에 긍정적인 효과가 일어나는데 이러한 적절한 진동과 저항이 신경조직의 물리적 능력을 회복시켜 일상생활에 관련된 능력이 향상 된 결과라고 생각된다. ${ }^{35,36}$

본 연구에서는 허리원반 탈출증 수술 후 증후군을 호소하는 환자 에게 신경가동술을 적용하였을 때 이상감각 및 교감신경에 어떠한 영향을 미치는지 살펴보았다. 신경 전도 속도와 피부반응에는 효과 가 미미했지만 이상감각 부분에서는 평균 점수가 감소하는 것으로 보아 신경가동술로 인한 말초신경의 적절한 긴장과 가동성을 통하 여 교감신경계에 긍정적 효과가 있었을 걸로 생각된다. 따라서 신경 가동술이 허리원반 탈출 수술 후 환자의 통증과 이상감각 호전에 있 
어 의미 있는 중재 치료법이 될 수 있다는 사실을 확인시켜 주었고 조 금 더 일찍 일상생활에 복귀할 수 있는 기회가 제공됨을 기대할 수 있 다. 그와 더불어 요부 안정화 운동과 함께 신경가동술을 적용하면 더 욱 긍정적인 효과를 기대한다.

그러나 신경가동술이 허리부분 교감신경계 및 연관된 신경들에 어떠한 변화를 일으켜 긍정적인 효과를 나타냈는지 명확히 알 수 없 었고 척추사이원반탈출로 인한 신경계에 작용하는 스트레스 및 민 감도 정도를 감각평가 도구로만 측정하였을 뿐 신경 구조에 대한 정 확한 평가를 하지 못했다. 또한 근전도 검사에 있어서 대상 환자의 진 단에 따른 뚜렷한 이상소견이 없어 중재방법에 따른 효율성을 입증 할 수 없었고, 수술법에 대한 이질성을 정확히 배제하지 못했다. 따라 서 향후 연구에서는 좀 더 많은 대상자를 선정하여 좀 더 구체적인 진 단명과 수술방법에 관련한 장기간의 연구 및 신경가동술을 통한 신 경들의 신경생리학적 관련한 연구가 필요하며 다양한 장비들을 통 해 좀 더 객관적으로 측정 및 평가할 수 있는 연구 또한 필요할 것으 로 사료된다.

본 연구는 허리원반 탈출증으로 진단을 받고 수술한 환자에게 신 경가동술이 수술 후 환자의 통증과 이상감각에 어떠한 영향을 미치 는지를 알아보고자 10 명의 허리원반 탈출증 수술 환자를 대상으로 1 주간 신경가동술을 적용하고 적용전과 후에 TCNSS와SSR측정을 통 해 다음과같은 결론을 얻었다.

첫째, 이상감각의 변화를 확인하기 위한 TCNSS 척도 점수에서 신 경가동술 적용 시 평균 점수가 감소하는데 매우 유의한 차이가 있었 다. 둘째, 교감신경 변화를 확인하기 위한 근전도 검사인 SSR검사에 서는 유의한차이가 없었다.

이러한 결과는 신경가동술이 허리원반 탈출 수술 후 환자의 교감 신경전도속도, 자율 신경계 피 부반응에는 영향을 주지 못했지만 이 상감각에 긍정적인 영향을 미쳐 통증 감소 및 다리저림과 같은 이상 감각의 호전을 유도하며, 이러한 연구 결과를 통하여 신경가동술은 허리원반 탈출증 수술 후 환자의 치료에 적극적으로 활용될 수 있을 것이라 생각된다.

\section{참고문헌}

1. Woolf AD, Pfleger B. Burden of major musculoskeletal conditions. Bulletin of the world health organization.2003;81:646-56.

2. Waddell G. Low back pain: A twentieth century health care enigma. Spine. 1996;21(24):2820-5.

3. Van Tulder MW, Koes BW, Bouter LM. Conservative treatment of acute and chronic nonspecific low back pain: A systematic review of randomized controlled trials of the most common interventions. Spine.1997; 22(18):2128-56.

4. Kuslich S, Ulstrom C, Michael C. The tissue origin of low back pain and sciatica: A report of pain response to tissue stimulation during operations on the lumbar spine using local anesthesia. Orthop Clin North Am. 1991;22(2):181-7.

5. Merskey H. Pain terms: A list with definitions and notes on usage. Recommended by the iasp subcommittee on taxonomy. Pain. 1979;6:24952.

6. Wilson DH, Kenning J. Microsurgical lumbar discectomy: Preliminary report of 83 consecutive cases. Neurosurgery. 1979;4(2):137-40.

7. Bertrand G. The "battered" root problem. Orthop Clin North Am. 1975; 6(1):305-10.

8. Fager CA. Lumbar microdiscectomy: A contrary opinion. Clin neurosurg. 1986;33:419-56.

9. Lundborg G, Rydevik B. Effects of stretching the tibial nerve of the rabbit: A preliminary study of the intraneural circulation and the barrier function of the perineurium. J Bone Joint Surg Br. 1973;55(2):390-401.

10. Millesi H. The nerve gap. Theory and clinical practice. Hand clinics. 1986;2(4):651-63.

11. Bove GM, Light AR. Calcitonin gene-related peptide and peripherin immunoreactivity in nerve sheaths. Somatosens Mot Res. 1995;12(1): 49-57.

12. Bove GM, Light AR. The nervi nervorum: Missing link for neuropathic pain? Pain forum. 1997;6:181-90.

13. Zochodne DW, Ho LT. Hyperemia of injured peripheral nerve: Sensitivity to cgrp antagonism. Brain Res. 1992;598(1-2):59-66.

14. Zochodne DW, Ho LT. Influence of perivascular peptides on endoneurial blood flow and microvascular resistance in the sciatic nerve of the rat. J Physiol. 1991;444:615-30.

15. Lundborg G, Dahlin LB. Anatomy, function, and pathophysiology of peripheral nerves and nerve compression. Hand Clin. 1996;12(2):18593.

16. Shacklock M. Clinical application of neurodynamics. Moving in on Pain. 1995:123-31.

17. Rozmaryn LM, Dovelle S, Rothman ER et al. Nerve and tendon gliding exercises and the conservative management of carpal tunnel syndrome. J Hand Ther. 1998;11(3):171-9.

18. Sweeney J, Harms A. Persistent mechanical allodynia following injury of the hand: Treatment through mobilization of the nervous system. J Hand Ther. 1996;9(4):328-38.

19. Vicenzino B, Collins D, Wright A. The initial effects of a cervical spine manipulative physiotherapy treatment on the pain and dysfunction of lateral epicondylalgia. Pain. 1996;68(1):69-74.

20. Cowell I, Phillips D. Effectiveness of manipulative physiotherapy for the treatment of a neurogenic cervicobrachial pain syndrome: A single case study-experimental design. Man Ther. 2002;7(1):31-8.

21. Elvey RL. Treatment of arm pain associated with abnormal brachial plexus tension. Aust J Physiother. 1986;32(4):225-30.

22. Bril V, Perkins BA. Validation of the toronto clinical scoring system for diabetic polyneuropathy. Diabetes Care. 2002;25(11):2048-52.

23. Jung TH, Park DS, Nam HS. Autonomic Function in Chronic Alcoholic Patients. Ann Rehabil Med. 2009;33(3):321-6.

24. Ostelo RW, Costa LO, Maher CG. Rehabilitation after lumbar disc surgery. Cochrane Datahase Syst Rev. CD003007. 2008

25. Gibson JN, Waddell G. Surgical interventions for lumbar disc prolapse: updated Cochrane Review, Spine. 2007;32:1735-47 
26. Butler DS. Upper limb neurodynamic test: Clinical use in a "big picture" framework. Physical therapy of the cervical and thoracic spine. Elsevier. 2002:200-14.

27. Ogata K, Naito M. Blood flow of peripheral nerve effects of dissection, stretching and compression. J Hand Surg. 1986;11(1):10-4.

28. Calvin WH, Devor M, Howe JF. Can neuralgias arise from minor demyelination? Spontaneous firing, mechanosensitivity, and afterdischarge from conducting axons. Exp neurol. 1982;75(3):755-63.

29. Hall T, Zusman M, Elvey R. Adverse mechanical tension in the nervous system? Analysis of straight leg raise. Man Ther. 1998;3(3):140-6.

30. Scrimshaw SV, Maher CG. Randomized controlled trial of neural mobilization after spinal surgery. Spine. 2001;26(24):2647-52.

31. Igarashi K. Pathogenesis of lumbo-sacral nerve root lesion: From the view point of thermographic findings of the lower limbs. Nihon Geka Hokan.1990;59(5):391-401.
32. O'Donnell ME, Badger SA, Anees SM et al. The effects of cilostazol on peripheral neuropathy in diabetic patients with peripheral arterial disease. Angiology. 2009;59(6):695-704.

33. Ghavami H, Shamsi SA, Soheili S et al. Effect of lifestyle interventions on diabetic peripheral neuropathy in patients with type 2 diabetes, result of a randomized clinical trial. Agri. 2018;30(4):165-70.

34. Kim JH, Han TR, Lee SU. The Effect of Transcutaneous Electrical Nerve Stimulation and Interference Curent Therrapy on the Autonomic Nervous System. J Kor Aca rehabil Med. 1996;20(3):658-63.

35. Coppieters MW, Butler DS. Do "sliders" slide and “Tensioner" tension? An analysis of neurodynamic techniques and considerations regarding their application. Man Ther. 2008;13(3);213-21.

36. Park JW, Kim SH, Nam KS et al. Effect of the upper limb nerve mobilization on functional recovery in hemiplegic patients following stroke, Phys Ther Korea. 2001;8(2)33-6. 